\title{
PARASITIC CILIATES (PROTOZOA, CILIOPHORA) OF THE COMMON BREAM, ABRAMIS BRAMA (L.) AND WHITE BREAM, BLICCA BJOERKNA (L.) FROM DĄBIE LAKE (POLAND) PASOŻYTNICZE ORZESKI (PROTOZOA, CILIOPHORA) U LESZCZA ABRAMIS BRAMA (L.) I KRAPIA BLICCA BJOERKNA (L.) Z JEZIORA DĄBIE (POLSKA)
}

\section{Department of Fish Diseases, Agricultural University of Szczecin, Poland}

A total of seven species of parasitic ciliates was recovered from the studied fishes of Dąbie Lake located in the estuary of the Odra River. The common bream harboured the following species: Chilodonella hexasticha, Ch. piscicola, Ichthyophthirius multifiliis, Trichodina modesta, and Trichodinella epizootica. The white bream turned out to be the host for: Ch. piscicola, Capriniana piscium, I. multifiliis, T. modesta, Tripartiella copiosa, and T. epizootica. Three of the above species constitute new records for the parasite fauna of the common bream in Poland, while five-new records for the white bream. Ciliates T. modesta are a new species for Polish parasite fauna. The white bream became a new host for $\mathbb{C}$. piscium. The measurements and photographs of T. modesta and T. copiosa are provided in this paper.

\section{INTRODUCTION}

Ciliates of the family Trichodinidae of the common bream, Abramis brama (L.) and the white bream, Blicca bjoerkna (L.) from Polish waters are poorly known. Only one species had been hitherto recorded from those two hosts, identified by the authors as Trichodina domerguei (Wallengren, 1897). These protozoans on the common bream were recorded from the Vistula River near Warsaw by Kozicka (1951) and from the Włocławski Reservoir by Waluga and Własow (1988). This species was also reported to infect gills of the white bream from the Vistula Lagoon and the Ma- 
surian Lake District by Wegener (1909) (cited after Grabda 1971). The other relevant publications on the common bream and white bream, list the protozoans found-on the generic level only-as Trichodina sp. They were found on the common bream from lake Warniak (Groba 1973) and from lake Kortowskie (Własow et al. 1991). On the white bream, the parasite was found in the Konin Lakes (Pojmańska et al. 1980) and on the hatch and fry of the white bream from lake Gosławskie (Niewiadomska 1977).

Among other ciliates, Ichthyophthirius multifiliis Fouquet, 1876 was recorded on the common bream (Grabda 1971) and the white bream (Grabda 1971; Niewiadomska 1977; Pojmańska et al. 1980). In addition to that, Chilodonella piscicola (Zacharias, 1894) was found on the common bream (Kozicka 1951) and Apiosoma sp.—on the white bream (Niewiadomska 1977; Pojmańska et al. 1980).

The aim of the present work was to contribute to the knowledge on the ciliates inhabiting the gills of the common bream and the white bream from Dąbie Lake. The present study will supplement scarce data on the above-mentioned hosts from the Polish waters. There have been no studies like this conducted hitherto in the Polish Western Pomerania.

\section{MATERIAL AND METHODS}

The fishes were collected from $\mathbb{D}$ ąbie Lake, connected with the estuarial section of the Odra River and located within the city limits of Szczecin. The present material was collected within 1969-1971 at the time of the survey of metazoan parasites (Wierzbicka 1974, 1977a, b, 1978). A total of 233 common bream, Abra-

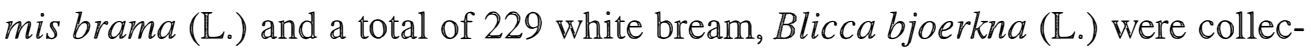
ted. The total lengths of the former ranged from 10.0 to $58.0 \mathrm{~cm}$, the age-from $1+$ to $10+$. The total lengths of the white bream ranged from 7.5 to $34.0 \mathrm{~cm}$ and their age was from $1+$ to $12+$.

During the necropsies performed on fresh fishes, the scrapped materiel from the gills was studied under microscope. Subsequently, the smears of the gills were prepared. Such preparations were silvered with the solution of $\mathrm{AgNO}_{3}$ (the method of Klein) or stained with the Delafield hematoxylin and mounted in the Canada balsam. The measurements of the ciliates were conducted according to the procedure adopted by Lom and Dyková (1992).

\section{RESULTS}

There were 7 species of parasitic ciliates found on the gills of the fishes surveyed. In this number 5 species on the common bream and 6 on the white bream.

Trichodina modesta Lom, 1970 (Figs. 1-5) occurred on both host species. They were recorded on 11 preparations from the common bream and on 10 from 


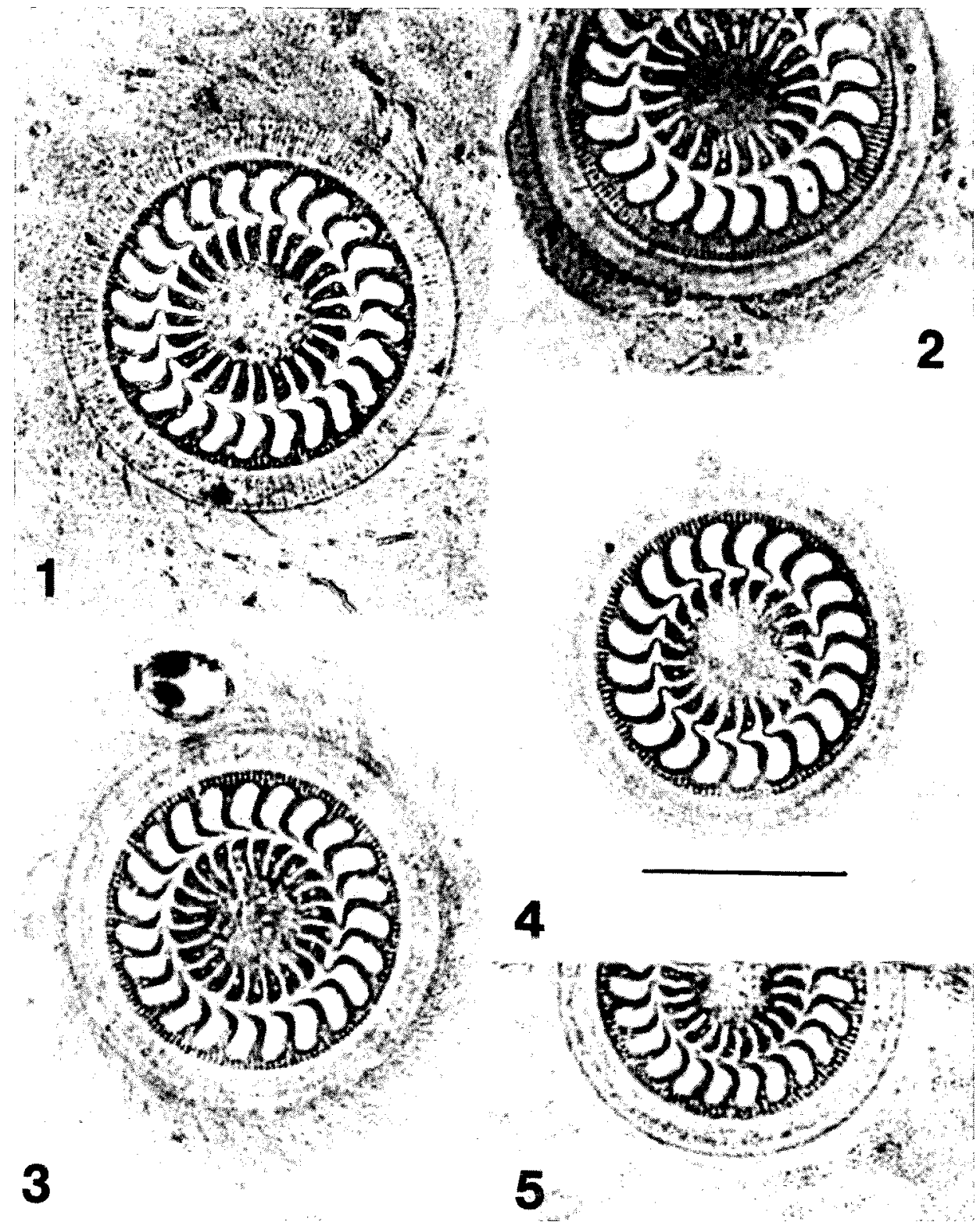

Figs. 1-5. Trichodina modesta; 1-3 from the gills of the common bream, 4, 5 from the gills of the white bream (scale bar $=20 \mu \mathrm{m})$

photographed by Mr. P. Śmietana 

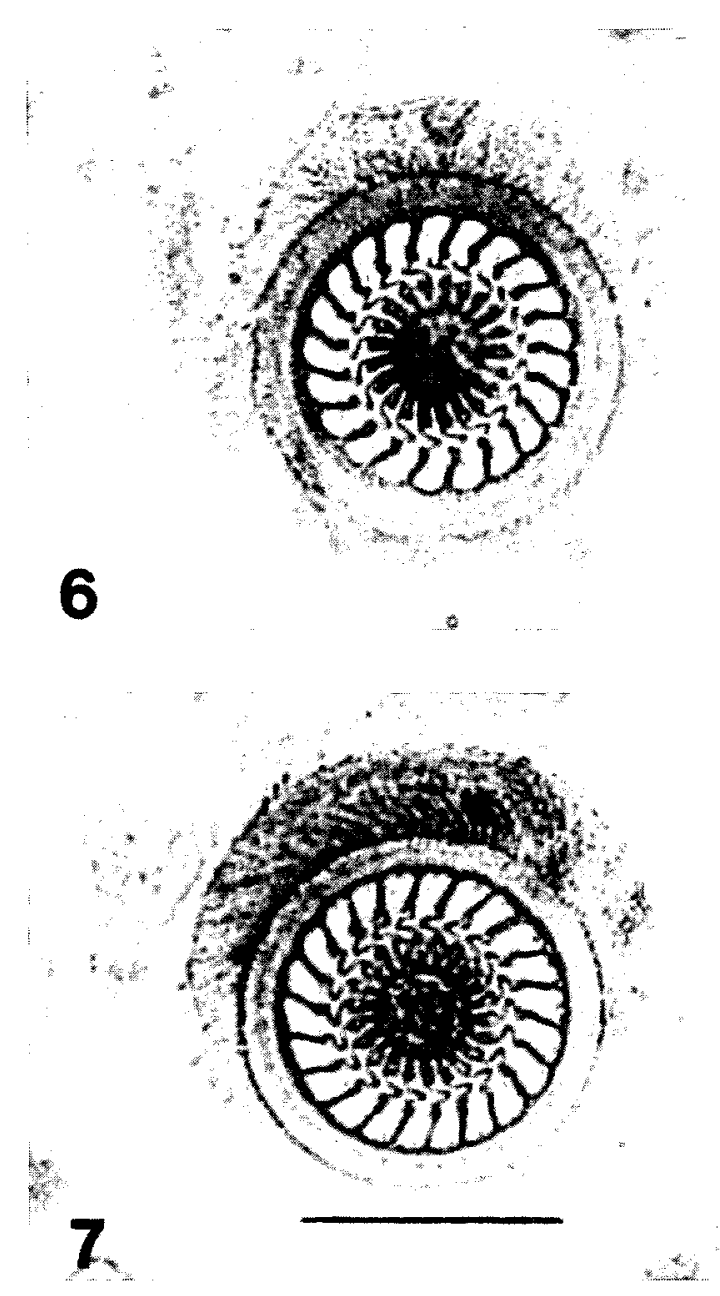

Figs. 6, 7. Tripartiella copiosa from the gills of the white bream (scale bar $=20 \mu \mathrm{m}$ ) photographed by Mr. P. Śmietana 
the white bream. In most cases the intensity of infection was low. The number of denticles in the adhesive disk, as well as the morphometric characters of the protozoans found on both hosts, turned out to be very similar (Tab. 1). In the population inhabiting the common bream, however, those values were slightly higher, than the respective ones in the white bream.

Table 1

Particulars concerning Trichodina modesta and Tripartiella copiosa

\begin{tabular}{|l|c|c|c|c|c|c|}
\hline Parasite species & \multicolumn{3}{|c|}{ Trichodina modesta } & \multicolumn{2}{c|}{ Tripartiella copiosa } \\
\hline Host & \multicolumn{2}{|c|}{ Abramis brama } & \multicolumn{2}{|c|}{ Blicca bjoerkna } & \multicolumn{2}{c|}{ Blicca bjoerkna } \\
\hline Diameter of: & Range & $\bar{x}$ & Range & $\bar{x}$ & Range & $\bar{x}$ \\
body & & & & & & \\
adhesive disc & $36.0-44.0$ & 39.8 & $32.4-40.0$ & 36.2 & $31.2-36.0$ & 32.9 \\
denticulate ring & $27.2-32.0$ & 29.2 & $23.2-30.4$ & 26.5 & $17.6-24.8$ & 21.2 \\
\hline Number of: & $15.6-20.0$ & 17.6 & $13.2-18.0$ & 15.3 & $9.6-13.6$ & 12.0 \\
denticles & & & & & & \\
radial pins/denticle & $22-25$ & 23.4 & $21-23$ & 22.2 & $20-23$ & 21.8 \\
\hline Dimension of denticles: & $6-7$ & & $6-7$ & & $4-5$ & \\
blade & & & & & & \\
thorn & $3.6-4.6$ & 4.1 & $3.2-4.4$ & 3.9 & $3.0-4.0$ & 3.5 \\
central part & $2.8-3.6$ & 3.3 & $2.8-3.4$ & 3.1 & $1.5-2.0$ & 1.8 \\
length & $1.2-1.6$ & 1.3 & $1.0-1.5$ & 1.2 & $1.2-1.5$ & 1.4 \\
Width of border membrane & $4.2-5.0$ & 4.6 & $4.0-5.2$ & 4.4 & $3.2-4.0$ & 3.4 \\
\hline
\end{tabular}

Dimensions in $\mu \mathrm{m}, \mathrm{n}=12$.

Tripartiella copiosa (Lom, 1959) (Figs. 6, 7) were found only on the gills of the white bream. Single or not numerous specimens of this species (up to 20 under a coverslip $24 \times 24 \mathrm{~mm}$ ) were encountered on 8 fish. The number of denticles in the adhesive disc and the dimensions of the ciliates are given in Tab. 1.

The other species-Trichodinella epizootica (Raabe, 1950) occurred on both hosts studied. Single specimens were recorded on the gills of four white bream and two common bream.

In addition to the above-mentioned parasitic ciliates, single specimens of Chilodonella piscicola (Zacharias, 1894) were found on the silvered preparations. They were present on three white bream and one common bream. The second species-Ch. hexasticha (Kiernik, 1909) was recovered form a single common bream only.

Examination of the fresh preparations yielded specimens of Ichthyophthirius multifiliis Fouquet, 1876 on both hosts. The prevalence of the infection of the common bream was $3.43 \%$, while that of the white bream- $4.37 \%$. The intensity 
of the infection was ranged from single to relatively numerous specimens. In addition to that, abundant specimens of Capriniana piscium (Bütschli, 1889) were present on the gills of one white bream.

Infection parameters of the individual species of the family Trichodinidae were undoubtedly higher. Some of the specimens, however, had their adhesive discs obscured what made proper identification, up to the species level, impossible.

\section{DISCUSSION}

Three species of the protozoans representing the family Trichodinidae were found on the surveyed common bream and white bream from Dąbie Lake. One of them-Trichodina modesta for the first time was found on the gills of zanthe, Vimba vimba (L.) from the former Czechoslovakia and the common bream from Hungary, and described by Lom (1970) as a new species. Subsequently it was recorded on the gills of the common bream from Kursk Bay (Stein 1982) and the white bream from the Rybinskij reservoir on the Volga River (Arthur and Lom 1984). The morphological and morphometric characters of T. modesta in the material presently analysed are consistent with the data of the above-mentioned authors. This is a new species for Polish parasite fauna.

Tripartiella copiosa described in the present paper appeared more often in the literature concerning different species (Šul'man 1984). These ciliates on the gills of the white bream in the former Czechoslovakia were recorded by Lom (1970), while a few specimens of this species on the same fish from the Rybinskij reservoir were mentioned by Arthur and Lom (1984). T. copiosa from Polish waters were described by Migała $(1976,1993)$. Those papers dealt with another fish species. The data on T. copiosa from the gills of the white bream listed in Tab. 1, are consistent with the results of Arthur and Lom (1984).

Trichodinella epizootica, contrary to the above-mentioned species, was more frequently found on different hosts from Polish waters (Grabda 1971; Migała 1976, 1993; Pilecka-Rapacz 1980; Wierzbicka and Orecka-Grabda 1994; Wierzbicka et al. 1998; and others). These protozoans, however, have not hitherto been found on the common bream and the white bream in the waters of our country.

Detailed discussion on the separate identity of Chilodonella piscicola and $\mathrm{Ch}$. hexasticha was given by Kazubski and Migała (1974), while a detailed description of Capriniana piscium was published by Prost (1952). The three above-mentioned species were found, among other fishes, also on the gills of the blue bream, Abramis ballerus (L.) form Dąbie Lake (Wierzbicka 1997). These ciliates have not hitherto been recorded on the common bream and white bream from Polish waters. The exception is Ch. piscicola reported previously from the common bream by Kozicka (1951). It is evident from the available literature and the data of Sul'man (1984) that the white bream is a new host for C. piscium. 


\section{CONCLUSIONS}

1. There were 7 species of parasitic ciliates found on the gills of the surveyed common bream and white bream. The common bream was infected by: Chilodonella hexasticha. Ch. piscicola, Ichthyophthirius multifiliis, Trichodina modesta, and Trichodinella epizootica. The white bream harbored: Ch. piscicola, Capriniana piscium, I. multifiliis, T. modesta, Tripartiella copiosa, and T. epizootica.

2. The following parasites turned out to be new for the common bream in Poland: Ch. hexasticha, T. modesta, and T. epizootica. New for the white bream in Poland were: Ch. piscicola, C. piscium, T. modesta, T. copiosa, and T. epizootica.

3. T. modesta is a new species for Polish parasite fauna, while the white bream is a new host for C. piscium.

\section{REFERENCES}

Arthur J. R., J. Lom, 1984: Trichodinid Protozoa (Ciliophora: Peritrichida) from freshwater fishes of Rybinsk Reservoir, USSR. J. Protozool., 31, 1: 82-91.

Grabda J. [ed.], 1971: Katalog fauny pasożytniczej Polski. (Catalogus faunae parasiticae Poloniae). II. Pasożyty krągłoustych i ryb. (Parasiti cyclostomatorum et piscium). [Catalogue of parasite fauna of Poland. II. Parasites of fishes and cyclostomates.] PWN, Warszawa-Wrocław. (In Polish).

Groba J., 1973: Experimentally increased fish stock in the pond type lake Warniak. V. Parasites of fish. Ekologia Polska, 21, 31: 505-518.

Kazubski S. L., K. Migała, 1974: Studies on the distinctness of Chilodonella cyprini (Moroff) and Ch. hexasticha (Kiernik) (Chlamydodontidae, Gymnostomatida), Ciliate parasites of fishes. Acta Protozool., 13, 3: 9-40.

Kozicka J.,1951: Pasożyty i stan zdrowotny leszcza - Abramis brama L. w Wiśle koło Warszawy. [Parasites and health conditions of bream from the Vistula River near Warsaw.] Rocz. Nauk Rol., 58: 341-372. (In Polish).

Lom J., 1970: Observations on trichodinid ciliates from freshwater fishes. Arch. Protistenk., 112: 153-177.

Lom J., I. Dykov, 1992: Protozoan parasites of fishes. Elsevier, Amsterdam-London-New York-Tokyo: 237-288.

Migała K., 1976: Parasitic Ciliata at the Ctenopharyngodon idella Val., Hypophthalmichthys molitrix Val. and Aristichthys nobilis Rich. in ponds. Wiad. Parazytol., 22, 4-5: 545-548.

Migała K., 1993: Parasitic Trichodinidae in salmonid fish cultured in Polish ponds. Arch. Ryb. Pol., 1, 2: 145-159.

Niewiadomska K., 1977: Pasożyty wylęgu i narybku niektórych gatunków ryb z jezior konińskich. [Parasites of hatchlings and of fry of some fish species from the Konin lakes complex.] Rocz. Nauk Rol., 97-H, 4: 45-59. (In Polish).

Pilecka-Rapacz M., 1980: Pierwotniaki ryb z rodziny Percidae Zalewu Szczecińskiego. [Protozoan parasites of the Szczecin Firth; Percidae.] Zesz. Nauk. AR., Szczecin, Seria: Rybactwo Morskie, 82: 75-86. (In Polish).

Pojmańska T., B. Grabda-Kazubska, S. L. Kazubski, J. Machalska, K. Niewiadomska, 1980: Parasite fauna of five fish species from the Konin lakes complex, artificially heated with thermal ef fluents, and from Gopło lake. Acta Parasitol. Pol., 27, 38: 319-357. 
Prost M., 1952: Badania nad pierwotniakami pasożytnymi skrzeli ryb. I. Trichophrya intermedia sp. n. na skrzelach narybku łososia. [Investigations on parasitic Protozoa on the gills of fishes. I. Trichophrya intermedia sp. n. on the gills of salmon fry]. Ann. Univ. Mariae Curie-Skłodowska, Lublin, Sect. C, 6, 12: 379-386. (In Polish).

Stejm, G.A., 1982: Parazitičeskie infuzorii (Peritrichida, Trichodinidae) nekotoryh ryb Kuršskogo Zaliva. [Parasitic ciliates (Peritrichida, Trichodinidae) of some fishes of the Kurish Gulf.] Parazitologija, 16, 1: 24-29. (In Russian).

Šul'man S. So, [ed.], 1984: Opredelitel' parazitov presnovodnych ryb fauny SSSR. I. Parazitičeskie prostejšie. [Guide to the parasites of freshwater fishes of the fauna of the USSR. I. Parasitic protozoans.] Izd. „Nauka”, Leningrad: 252-389. (In Russian).

Waluga D., T. Wlasow, 1988: Występowanie pasożytów u leszcza (Abramis brama L.), płoci (Rutilus rutilus L.) i sandacza (Stizostedion lucioperca L.) we Włocławskim Zbiorniku Zaporowym na rzece Wiśle. [The occurrence of parasites in bream (Abramis brama L.), roach (Rutilus rutilus L.) and pike perch (Stizostedion lucioperca L.) in the Włocławek Dam Reservoir on the river Vistula.] Wiad. Parazytol., 34, 1: 65-75. (In Polish).

Wierzbicka J., 1974: Monogenoidea of gills of certain Cyprinidae fish species. Acta Parasitol. Pol., 22, 13: 149-163.

Wierzbicka J., 1977a: Trematodes of Abramis brama, A. ballerus and Blicca bjoercna from the Dąbie lake, Poland. Acta Parasitol. Pol., 25, 1:1-16.

Wierzbicka Jo, 1977b: An attempt to explain affinities between Blicca bjoerkna (L.), Abramis brama (L.), and A. ballerus (L.) on the grounds of their parasitic fauna. Acta Ichthyol. Piscat., 7, 1: 3-13.

Wierzbicka J., 1978: Cestoda, Nematoda, Acanthocephala, Hirudinea and Crustacea from Abramis brama, A. ballerus and Blicca bjoercna of the Dąbie lake, Poland. Acta Parasitol. Pol., 25, 36: 293-305.

Wierzbicka J., 1997: Ciliates (Ciliophora) parasitic on the gills of the blue bream Abramis ballerus (L.) from Dąbie Lake (Poland). Acta Ichthyol. Piscat., 27, 2: (in press).

Wierzbicka J., T. Orecka-Grabda, 1994: Protozoans parasitic on Anguilla anguilla (L.) from the Szczecin Lagoon and River Odra mouth. Acta Ichthyol. Piscat., 24, 2: 3-11.

Wierzbicka J., E. Sobecka, D. Gronet, 1998: Parasitic fauna of the tench, Tinca tinca (L.) from selected lakes of the north-western regions of Poland. Acta Ichthyol. Piscat., 28, 1: (in press).

Whasow T., $\mathbb{K}$. Kulkliński, $\mathbb{B}$. Majewska, M. Skrok, 1991: Parazytofauna wzdręgi (Scardinius erythrophthalmus) i leszcza (Abramis brama) z jeziora poddanego oligotrofizacji. [Parasite fauna of the rudd (Scardinius erythrophthalmus) and the common bream (Abramis brama) from a lake subjected to oligotrophication.] Materiały XVI Zjazdu Pol. Tow. Parazytol., Poznań, 12-13 września 1991: 34. (In Polish). 
Jadwiga WIERZBICKA

PASOŻYTNICZE ORZĘSKI (PROTOZOA, CILIOPHORA) U LESZCZA ABRAMIS $B R A M A$ (L.) I KRĄPIA BLICCA BJOERKNA (L.) Z JEZIORA DĄBIE (POLSKA)

\section{STRESZCZENIE}

Na skrzelach badanych leszczy i krąpi z jeziora Dąbie, mającego bezpośrednie połączenie z ujściowym odcinkiem rzeki Odry, znaleziono 7 gatunków pasożytniczych orzęsków. U leszcza występowały: Chilodonella hexasticha, Ch. piscicola, Ichthyophthirius multifiliis, Trichodina modesta i Trichodinella epizootica. U krąpia stwierdzono: Ch. piscicola, Capriniana piscium, I. multifiliis, T. modesta, Tripartiella copiosa i T. epizootica. $\mathrm{Z}$ wyżej wymienionych pierwotniaków nie były dotychczas notowane w wodach Polski u leszcza trzy gatunki: Ch. hexasticha, T. modesta i T. epizootica, natomiast u krąpia pięć gatunków: Ch. piscicola, C. piscium, T. modesta, T. copiosa i T. epizootica.

Orzęski $T$. modesta są nowym gatunkiem dla parazytofauny Polski, natomiast krąp jest nowym żywicielem pierwotniaków $C$. piscium.

$\mathrm{W}$ pracy zamieszczono wymiary i fotografie orzęsków $T$. modesta $i$ T. copiosa.

Received: 14 August 1997

Authors' address:

Jadwiga Wierzbicka PhD DSc

Department of Fish Diseases

Agricultural University of Szczecin

Kazimierza Królewicza 4, 71-550 Szczecin, Poland 